代議員選挙について

平成29年総会時に選任される新代議員選出のための選挙を実施いたします。

立候補手続きは正会員が所属する支部（勤務機関所在地）を通して行われます。

一般社団法人日本老年医学会「定款」「定款細則」「代議員専任細則」「代議員選挙管理細則」 をホームページに掲載しておりますので、ご参照ください。

〈公示〉についても、ホームページに掲載しております。

\title{
〈公示〉
}

平成28年7月 25 日

一般社団法人 日本老年医学会 正会員各位

一般社団法人 日本老年医学会 平成28 年選挙管理委員会

\section{一般社団法人日本老年医学会 平成28年代議員選挙に関するお知らせ}

平成29年総会時に選任される新代議員選出のための選挙を、平成28年8月から12月までの 期間中に行いますのでご案内申し上げます。

I . 各支部別代議員定数(平成 28 年 6 月 1 日の正会員数と定員数)

\begin{tabular}{|c|c|c|c|}
\hline 支部名 & 正会員数 & 定数下限 & 定数上限 \\
\hline 北海道 & 248 & 24 & 27 \\
\hline 東北 & 308 & 30 & 33 \\
\hline 関東甲信越 & 2,267 & 220 & 246 \\
\hline 東海 & 635 & 62 & 69 \\
\hline 北陸 & 229 & 22 & 25 \\
\hline 近畿 & 1,001 & 97 & 108 \\
\hline 中国 & 500 & 49 & 54 \\
\hline 四国 & 328 & 32 & 36 \\
\hline 九州 & 664 & 64 & 72 \\
\hline 計 & 6,180 & 600 & 670 \\
\hline
\end{tabular}

各支部での被選挙人数が定数上限を超えたときには投票となります。

各支部での被選挙人数が定数下限未満のときは再募集します。

各支部での被選挙人数が上限・下限の定数内の場合は無投票選任となります。

\section{II. 選挙日程}

(1) 立候補受付:

(2) 再募集(定数下限未満の支部のみ):

(3) 選挙人および被選挙人公示:

平成 28 年 8 月 8 日 9 月 12 日

平成 28 年 9 月 13 日 9 月 30 日

平成 28 年 10 月 1 日以降

(4) 投票 (定数上限を超える支部の夕) :

(5) 開票:

(6) 当選者の公示:

平成 28 年 11 月 1 日 11 月 30 日

平成 28 年 12 月 1 日

(7) 当選者の選任:

平成 28 年 12 月 2 日以降

平成 29 年度定時社員総会 


\section{III. 立候補について}

\section{1. 立候補者の資格}

(1)原則として一般社団法人日本老年医学会正会員歴が5年以上あること（ただし、支部長 から日本老年医学会の学術的発展に対し特に必要との要請があり、選挙管理委員会によ りその必要性が認められた場合は、正会員歴5年未満であっても立候補できる場合があ ります。)

(2)平成29年3月31日時点で満69歳未満であること。

2. 立候補の届出

(1)届出事項

【立候補者プロフィール】このプロフィールの一部は被選挙人の情報として公示されます。

【推薦書】現代議員5名の自著による推薦が必要です。

け現代議員の場合：【立候補者プロフィール】のみご提出ください。

、新規立候補の場合：【立候補者プロフィール】【推薦書】をご提出ください。

(2)届出方法

•現代議員の場合：8月初旬に日本老年医学会より、立候補についてのご案内をメールにて 送信いたします。インターネットで登録申請してください。

、新規立候補の場合：所属する支部事務局（後掲）に、氏名・ご所属を明記の上、所属 する支部へメールあるいは、はがき等で提出書類をご請求ください。折り返し支部事

務局よりご連絡いたします。

(3)受付期間

$$
\text { 平成28年8月8日～9月 } 12 \text { 日（必着） }
$$

\section{IV. 投票方法}

各支部の被選挙人数が、定数上限を超えた場合は無記名投票となります。

1. 正会員に対し、所属する支部の被選挙人一覧、投票用紙、返信用封筒を日本老年医学会事 務局より郵送いたします（平成28年10月中）。無記名投票用紙を日本老年医学会選挙管理 委員会へ返送してください。（平成28年11月1日〜11月30日必着）

2. 投票用紙に記入する被選挙人の人数は、関東甲信越支部、近畿支部においては、異なる被 選挙人名 20 名連記、それ以外の支部においては異なる被選挙人名 10 名連記となります。 
支 部（提出書類の請求先・送付先）

北海道（支部長 下濱 俊 札幌医科大学 神経内科 教授）

支部事務局：=060-8543 北海道札幌市中央区南1 条西16 丁目

札幌医科大学 神経内科 川又 純

e-mai I: jkawamata@sapmed. ac. jp

東 北 (支部長 荒井 啓行 東北大学加齢医学研究所 老年医学分野 教授)

支部事務局：干980-8574 宮城県仙台市青葉区星陵町4-1

東北大学加齢医学研究所 老年医学分野 加藤淳子

e-mail: junko.kato.a7@tohoku. ac.jp

関東甲信越（支部長 下門 顕太郎 東京医科歯科大学 老年病内科 教授）

支部事務局：干113-8519 東京都文京区湯島1-5-45

東京医科歯科大学 老年病内科 金子英司

e-mail: asami_s.vasc@tmd. ac.jp

東 海（支部長 葛谷雅文 名古屋大学地域在宅医療学 - 老年科学分野 教授)

支部事務局：干466-8560 愛知県名古屋市昭和区鶴舞町65

名古屋大学地域在宅医療学・老年科学分野 梅垣宏行

e-mail: e-tomita@med. nagoya-u. ac. jp

北 陸（支部長 森本 茂人 金沢医科大学 高齢医学 教授）

支部事務局：=920-0293 石川県河北郡内灘町大学1-1

金沢医科大学 高齢医学 岩井邦充

e-mail: kiwai@kanazawa-med. ac.jp

近 畿 (支部長 横出 正之 京都大学医学部附属病院 臨床研究総合センター早期臨床試験部 教授)

支部事務局：=606-8507 京都市左京区聖護院川原町54

京都大学医学部附属病院 臨床研究総合センター早期臨床試験部 細谷歩美

e-mail: jgskinki@kuhp. kyoto-u. ac. jp

中 国 (支部長 山口 修平 島根大学医学部内科学講座内科学第三 教授)

支部事務局：=693-8501 島根県出雲市塩冶町89-1

島根大学医学部 内科学講座内科学第三 和田靖子

e-mai I: wadayasu@med. shimane-u. ac. jp

四 国 (支部長 北岡 裕章 高知大学医学部 老年病·循環器内科学 教授)

支部事務局：干783-8505 高知県南国市岡豊町小蓮

高知大学医学部 公衆衛生学 宮野伊知郎

e-mail : miyanoi@kochi-u. ac. jp

九 州 (支部長 大石 充 鹿児島大学 心臓血管·高血圧内科学 教授)

支部事務局：干890-8544 鹿児島市桜ヶ丘8丁目35-1

鹿児島大学 心臓血管 - 高血圧内科学 池田義之

e-mail: hiroco16@m. kufm. kagoshima-u. ac.jp

*選挙に関するご質問などは日本老年医学会事務局までお願いいたします。

一般社団法人 日本老年医学会 事務局：干113-0034 東京都文京区湯島 4-2-1 杏林ビル 702

TEL : 03-3814-8104 FAX : 03-3814-8604

e-mai1:jgs@blue.ocn.ne.jp 


\section{会員登録事項変更届}

下記の通り連絡します

$$
\text { 年月日 }
$$

該当する項目を○で囲んでください

1 . 自宅住所変更

2. 勤務先変更

3. 学会誌送付先変更

4. 退会 ※会費完納の上ご提出ください

5. その他

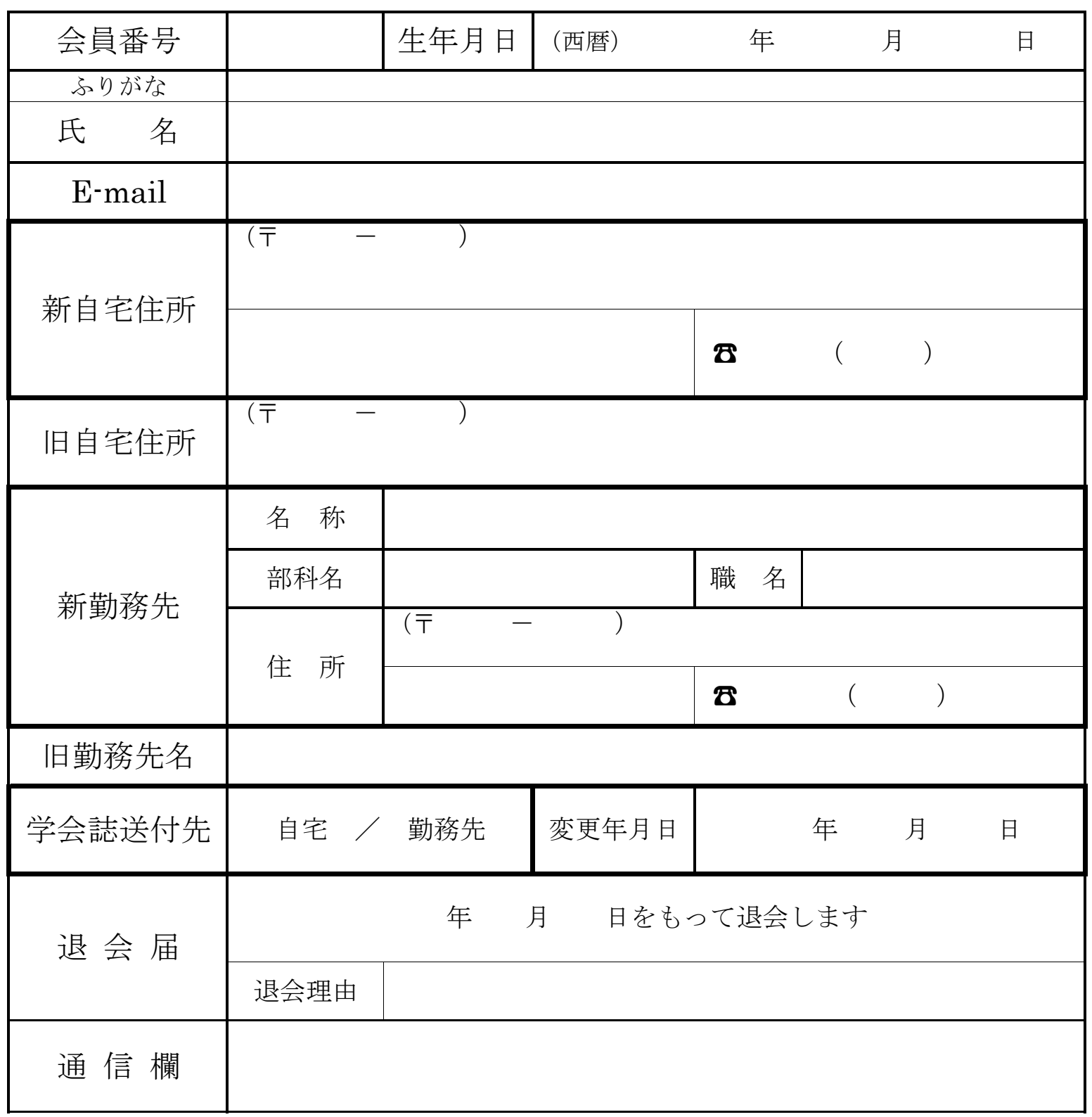

一般社団法人日本老年医学会 事務局

干113-0034 東京都文京区湯島4-2-1 杏林ビル702

TEL : 03-3814-8104 / FAX : 03-3814-8604

E-mail : jgs@blue.ocn.ne.jp 


\title{
《2017 年度日本老年学会総会・日本老年医学会学術集会開催のご案内》
}

\section{会員各位}

時下，会員の皆様におかれましては益々ご健勝のこととお慶び申し上げます. 2017 年度第 59 回日本老年医学会は第 59 回日本老年社会 科学会大会, 第 40 回日本基礎老化学会大会, 日本老年歯科医学会第 28 回学術大会, 第 32 回日本老年精神医学会, 第 16 回日本ケアマネ ンジメント学会研究大会, 第 22 回日本老年看護学会学術集会との合同により, 第 30 回日本老年学会総会として下記のと抢り開催を予定 いたしております．多数ご参加くださいますようご案内申し上げます.

\author{
第 30 回日本老年学会総会会長 大島 伸一 \\ 第 59 回日本老年医学会学術集会会長 鳥羽 研二 \\ 第 59 回日本老年社会科学会大会大会長 鈴木 隆雄 \\ 第 40 回日本基礎老化学会大会大会長 丸山 光生 \\ 日本老年歯科医学会第 28 回学術大会大会長 櫻井 薰 \\ 第 32 回日本老年精神医学会大会長 岸本 年史 \\ 第 16 回日本ケアマネジメント学会研究大会大会長 遠藤 英俊 \\ 第 22 回日本老年看護学会学術集会会長 鈴木みずえ
}

会 期 : 2017 年 6 月 14 日 (水), 15 日 (木), 16 日（金）
会 場 : 名古屋国際会議場, 愛知県産業労働者センターウインクあいち

第 30 回日本老年学会

会長 大島伸一 (国立長寿医療研究センター 名誉総長)

学会テーマ：「治し支える医療」へ向けて, 医学と社会の大転換を

プログラム

特別講演

会長講演

7 学会共同企画シンポジウム I XV

合同ポスターセッション

第 59 回日本老年医学会

会長 鳥羽研二（国立長寿医療研究センター 理事長）

学会テーマ: 老年医学とアート

プログラム

会長講演

招請講演

特別講演

シンポジウム

教育講演

ノバルティス老化および老年医学研究基金 2015 年受賞者講演

高齢者医療研修会（総合評価加算に関わる研修）

市民公開講座

一般演題提出締切日 2016 年 12 月 15 日（木）

演題募集要項は次号に掲載いたします.

演題応募は日本老年医学会ホームページを用いたオンライン登録になります.

登録受付開始は 2016 年 10 月 24 日（月）を予定しております. 
複写される方へ

本会は下記協会に複写に関する権利委託をしていますので, 本誌に揭載された著作物を複写したい方は, 同協会より許諾を受けて複写して下さい. 但し (公社) 日本複製権センター(同協会より権利を再委託) と包括複写許諾契約を締結されている企業の社員による社内利用目的の複写はその必要 はありません. (社外頒布用の複写は許諾が必要です.)

権利委託先 : $107-0052$ 東京都港区赤坂 9-6-41 乃木坂ビル (一社) 学術著作権協会

電話(03) 3475-5618 Fax (03)3475-5619 E-mail : info@jaacc.jp

なお，著作物の転載・翻訳のような, 複写以外の許諾は, 学術著作権協会では扱っていませんので, 直接本会へご連絡下さい.

また, アメリカ合衆国において本書を複写したい場合は，次の団体に連絡して下さい.

Copyright Clearance Center, Inc. 222 Rosewood Drive, Danvers, MA 01923 USA Phone 1-978-750-8400 Fax 1-978-646-8600 